\title{
Застосування ультразвукової навігаціі в хірургічному лікуванні вогнепальних ран
}

\author{
Е. В. Світличний ${ }^{1}$, О. С. Герасименко ${ }^{2}$, К. Р. Мурадян ${ }^{2}$ \\ 'Українська військово-медична академія, м. Київ, \\ ${ }^{2}$ Військово-медичний клінічний центр Південного регіону, м. Одеса

\section{Application of ultrasonic navigation in surgical treatment of a gun-shot wounds}

\author{
E. V. Svetlichniy ${ }^{1}$, O. S. Gerasimenko' ${ }^{2}$ K. R. Muradian ${ }^{2}$ \\ ${ }^{1}$ Ukrainian Military-Medical Academy, Kyiv, \\ ${ }^{2}$ Military-Medical Clinical Centre of Southern Region, Odesa
}

\begin{abstract}
Peферат
Мета. Поліпшення результатів лікування постраждалих з вогнепальними осколковими і кульовими пораненнями шляхом широкого використання комплексу ультразвукової та рентгенологічної навігації.

Матеріали і методи. Наведено досвід лікування 198 постраждалих із сліпими кульовими й осколковими пораненнями м'яких тканин на II рівні надання медичної допомоги в умовах АТО на базі 61, 65 і 66 військово-мобільних госпіталів. У діагностиці і видаленні чужорідних тіл (куль і осколків) під час хірургічної обробки ран використана рентгенологічна й ультразвукова навігація. Переважали пацієнти з множинними осколковими пораненнями.

Результати. Застосування сонографії дозволило лоціювати і видалити сторонні тіла у 95,4\% поранених, знизити частоту повторних операцій і скоротити терміни лікування.

Висновки. Перевагами методу сонографії є: мобільність, висока інформативність щодо структурних порушень м'яких тканин і верифікації чужорідних тіл, особливо не металевих. Видалення сторонніх тіл під контролем ультразвуку дозволяє проводити операцію в режимі реального часу без променевого навантаження на пацієнта і медичний персонал. Ключові слова: інтервенційна сонографія; ультразвукова навігація; вогнепальні рани.

Abstract

Objective. Improvement of the treatment results in injured persons with a gun-shot shrapnel woundings, widely using complex of ultrasonic and roentgenologic navigation.

Materials and methods. Experience of treatment of 198 injured persons with blind bullet and shrapnel woundings of soft tissues on the II level of the medical help provision in conditions of antiterrorist operation on base of 61, 65 and 66 militarymobile hospitals is demonstrated. Roentgenologic and ultrasound navigation was applied while doing surgical processing for diagnosis and remove of foreign bodies (bullets and shrapnel). The patients with multiple shrapnel woundings prevailed. Results. Application of sonography have permitted to locate and remove foreign bodies in $95.4 \%$ wounded persons, to lower the reoperations rate and shorten the treatment duration.

Conclusion. There are following advantages of sonography method: mobility, high informativeness concerning structural disorders of soft tissues and verification of foreign bodies, peculiarly of nonmetallic. Remove of foreign bodies under control of ultrasound permits to conduct operation in regime of real time without radiation load on the patient and medical personnel.

Keywords: interventional sonography; ultrasonic navigation; gun-shot wounds.
\end{abstract}

Видалення сторонніх тіл є однією з умов успішного лікування вогнепальної рани $[1,2]$. Сторонні тіла - кулі й осколки - 3 тканин організму видаляють під час первинної або повторної хірургічної обробки з використанням різних модифікацій магнітів, із застосуванням рентгенологічної навігації, а саме рентгеноскопії, електроннооптичного перетворювача (ЕОП), спіральної ком'ютерної томографії (СКТ), коли медичний персонал зазнає великих променевих навантажень, а у випадках неконтрастних чужорідних тіл знайти і видалити осколки буває важко [3]. Альтернативним методом навігації є ультразвукова діагностика. Однак дані про можливості іiі застосування досить обмежені. У зв'язку з цим ми ділимося власним досвідом використання ультразвукової навігації на II рівні надання медичної допомоги постраждалим з вогнепальними пораненнями в умовах АТО в Україні.

Мета дослідження: поліпшення результатів лікування постраждалих 3 вогнепальними осколковими і кульо- вими пораненнями шляхом широкого використання комплексу ультразвукової та рентгенологічної навігації в процесі видалення снарядів, що ранять, під час первинної і повторної хірургічної обробки.

\section{матеріали та методи дослідження}

Спостереження проведено щодо 198 постраждалих із вогнепальними сліпими кульовими й осколковими пораненнями, яких лікували в умовах 61, 65 і 66 військовомобільних госпіталів II рівня надання медичної допомоги за період з 2016 по 2017 рік. Для дослідження відбирали постраждалих, яким за медичними показаннями і оперативно-тактичним становищем було можливо видалення сторонніх тіл на даному рівні надання хірургічної допомоги. Всі постраждалі були розділені на дві групи - основну та контрольну. Основну групу склали 112 поранених, у яких осколки з рани м'яких тканин видаляли з використанням комплексу рентгенологічної (рент- 


\begin{tabular}{|c|c|c|c|c|c|c|c|c|c|c|c|c|c|c|}
\hline \multicolumn{15}{|c|}{ Структура розподілу поранених з урахуванням характеру поранення і тяжкості стану } \\
\hline \multirow{3}{*}{$\begin{array}{c}\text { Група } \\
\text { поранених }\end{array}$} & \multicolumn{8}{|c|}{ Характер поранень } & \multicolumn{6}{|c|}{ Тяжкість стану } \\
\hline & \multicolumn{2}{|c|}{ кульові } & \multicolumn{2}{|c|}{ осколкові } & \multicolumn{2}{|c|}{ одиничні } & \multicolumn{2}{|c|}{ множинні } & \multicolumn{2}{|c|}{ легкий } & \multicolumn{2}{|c|}{$\begin{array}{c}\text { середньої } \\
\text { тяжкості }\end{array}$} & \multicolumn{2}{|c|}{ тяжкий } \\
\hline & абс. & $\%$ & абс. & $\%$ & абс. & $\%$ & абс. & $\%$ & абс. & $\%$ & абс. & $\%$ & абс. & $\%$ \\
\hline Основна & 14 & 12,5 & 98 & 87,5 & 48 & 42,9 & 64 & 57,1 & 88 & 78,5 & 18 & 16,1 & 6 & 5,4 \\
\hline Контрольна & 10 & 11,6 & 76 & 88,3 & 39 & 45,3 & 47 & 54,7 & 67 & 77,9 & 13 & 15,1 & 6 & 7 \\
\hline Всього ... & 24 & 12,2 & 174 & 87,9 & 87 & 43,9 & 111 & 56,1 & 155 & 78,3 & 31 & 15,7 & 12 & 6,1 \\
\hline
\end{tabular}

геноскопія, рентгенографія) і ультразвукової навігації. Контрольну групу склали 86 поранених, у яких осколки видаляли під час хірургічної обробки традиційно - тільки з використанням рентгенологічної навігації.

В обох групах переважали постраждалі із сліпими множинними осколковими пораненнями легкого і середнього ступенів тяжкості, які були обумовлені множинним і поєднаним характером травми, проникаючими пораненнями, шоком, крововтратою (див. таблищю). В основній групі у 4 постраждалих поранення м'яких тканин поєднувалося 3 проникаючими пораненнями живота, у 2 - 3 пошкодженням грудної клітки і гемопневмотораксом, у 2 - 3 пошкодженням магістральних судин, у 16 - з вогнепальними переломами кісток верхніх і нижніх кінцівок. У 32 (28,6\%) поранених діагностували акубаротравму. У порівняльній групі у 2 постраждалих поранення м'яких тканин поєднувалося з проникаючими пораненнями живота, у 3 - $з$ пошкодженням грудної клітки і гемопневмотораксом, у 1 - 3 пошкодженням магістральних судин, у 14 - 3 вогнепальними переломами кісток верхніх і нижніх кінцівок. У 21 (24,4\%) пораненого діагностували акубаротравму. Обидві групи пацієнтів за характером поранень і тяжкості стану репрезентативнi $(\mathrm{p}<0,05)$.

Обсяг операцій відповідав стандартам II рівня етапного лікування - кваліфікованій допомозі. Порядок евакуації та ії вид (автомобільний, залізничний або авіаційний транспорт) визначалися характером поранення, тяжкістю стану потерпілого і оперативно-тактичним становищем. Передопераційне обстеження пацієнтів з метою верифікації структури пошкоджень включало клінічні, лабораторні та інструментальні методи: ультразвукове дослідження, рентгенографію, рентгеноскопію, в тому числі із застосуванням ЕОП.

\section{Результати}

При сліпих пораненнях сторонні тіла видаляли під час первинної або повторної хірургічної обробки вогнепальної рани в умовах стабілізаційних пунктів і військово-мобільних госпіталів. Снаряди, що ранили, локалізувалися в підшкірно-жировій, передочеревинній клітковині, м'язовому масиві. У лікуванні поранених контрольної групи застосовували стандартну концепцію. Поверхнево розташовані чужорідні тіла видаляли, по можливості, під час первинної хірургічної обробки вогнепальної рани після попередньої рентгенологічної навігації. 3 цією метою використовували різні модифікації магнітів за технологією ендовульнарного і зовнішнього застосування. У першому випадку магніт заводився в розширений рановий канал, металеві предмети підтягувалися до нього, і їх видаляли з рани; у другому - більш потужний магніт прикладався до поверхні шкіри або до введеного в рану затискача. Під дією магнітного поля куля або осколок притягувався до магніту, після чого його видаляли з рани. У частини поранених чужорідні тіла підтягувалися під шкіру, тоді над зоною деформації окремим доступом їх видаляли з рани. У разі глибокого розташування у м'язовому масиві в огрядних пацієнтів видалення осколків було пов'язане з певними труднощами. У таких ситуаціях під час повторної хірургічної обробки виконували широке розсічення рани для ревізії, використовували ЕОП, що давало можливість отримати картину просторового розташування чужорідного тіла, і видаляли його в режимі реального часу.

Однак у разі масового надходження поранених тривала робота з рентгенологічними приладами, незважаючи на індивідуальні засоби захисту, призводила до значного променевого навантаження на медичний персонал. Маніпуляції поблизу великих судин і нервових стовбурів мали високий ризик їх пошкодження. Такі матеріали, як скло, дерево, тканина, пластик, не диференціювалися в рентгенівських променях.

Під час первинної хірургічної обробки сторонні предмети вилучені у 55 (63,9\%) з 86 поранених, під час повторної - у 19 (22,1\%). У 12 (14\%) постраждалих кулі й осколки вилучені на III і IV етапах надання медичної допомоги. Причинами невдалого вилучення були: глибоке залягання осколків - у 4 (4,7\%) постраждалих, розташування поблизу великих судин - у 3 (3,5\%), неконтрастні в рентгенівських променях сторонні предмети - у 5 (5,8\%). Серед ускладнень у 2 поранених спостерігали кровотечу.

Розміри видалених сторонніх тіл за даними післяопераційних вимірювань: більше 3 см - у 5 (5,8\%) поранених, 2 - 3 см - у 10 (11,6\%), 1 - 2 см - у 27 (31,4\%), 0,3 1 см - у 44 (51,5\%). Чужорідні тіла з металу (деформовані кулі, оболонки куль, осколки снарядів) вилучені у 78 (91\%) поранених, скла - у 4 (4,7\%), каменю - у 2 (2,3\%), дерева - у 1 (1,2\%), пластику - у 1 (1,2\%). Таким чином, у 82,6\% поранених контрольної групи переважали металеві осколки розмірами до 2 см.

3 огляду на зазначені недоліки стандартної концепції, в основній групі ми додатково застосували ультразвукову навігацію з метою верифікації та видалення сторонніх тіл.

Метод сонографії в комплексі діагностики вогнепальної рани однозначно мав ряд переваг: добре диференціювалися тканини 3 нормальною ехоструктурою; візуально визначалися діаметр, напрямок і глибина ранового каналу; диференціювалася межа зони альтерації і непошкоджених тканин; візуалізувалися великі судини, нервові стовбури, сухожилля і кісткові структури, 
що зменшувало ймовірність їх пошкодження під час хірургічних маніпуляцій; диференціювалися всі види чужорідних тіл у м'яких тканинах; можливість проведення дослідження в палаті, перев'язочній, операційній, відділенні інтенсивної терапії. Металевим елементам було притаманне сильне відображення ультразвукового променя. При скануванні чітко візуалізувалися яскравий гіперехогенний утвір з наявністю прямих геометричних рис та гострих кутів у контурі, артефакти дистального підсилення ультразвуку за типом «хвоста комети» 3 чіткими паралельними гіперехогенними рисочками, дистального послаблення ультразвуку за типом «ультразвукової тіні».

Істинний розмір предмета встановити було складно, зважаючи на неправильність форми, особливості орієнтації у тканинах і артефакти ультразвуку, пов'язані з наявністю металу, газу та рідини у рановому каналі. У випадках сторонніх тіл у паренхіматозних органах візуалізували «вільну рідину» та гіпоехогенні згортки крові в рановому каналі та навколо пошкодженого органу, в черевній порожнині, заочеревинному просторі.

Сторонні тіла пластикові, скляні та з дерева, каменя мали чіткі форми, підвищену ехогенність і ефект дистального ослаблення ультразвуку. Форма була різною: лінійна, округла, кутова. У разі потрапляння в рану елементів одягу, візуалізували гіперехогенну структуру неправильної форми, різних розмірів, при достатньому збільшенні зображення - клітчастий малюнок волокон тканини. Структура була неоднорідною за рахунок крові, ексудату та газу.

Методика видалення сторонніх тіл: за даними первинного рентгенологічного дослідження визначали область розташування і топографічні орієнтири щодо кісткових структур і спеціальних маркерів. Виконувалося ультразвукове дослідження даної області, завданнями котрого були візуалізація стороннього тіла, визначення глибини залягання від поверхні шкіри, напрямок ранового каналу і диференціація анатомічно важливих структур (судин, нервів, сухожиль) для виключення можливого їх пошкодження. Визначався орієнтований найкоротший шлях для доступу до чужорідного тіла в обхід судин, великих нервових структур і сухожиль. Після застосування місцевої анестезії або внутрішньовенного наркозу скальпелем розширювали вхідний отвір на шкірі до $1-3$ см з видаленням явно нежиттездатних тканин. Під контролем ультразвуку виконували діагностичну пункцію голкою Chiba18-20G, яку по наміченому шляху підводили безпосередньо до чужорідного тіла. Тактильне відчуття дотику кінчика голки з металом, деревом, каменем або склом було остаточною верифікацією діагнозу. Після цього по ходу голки прямим або зігнутим затискачем поступово розширювали рановий канал під безпосереднім візуальним контролем на екрані монітора ультразвукового апарата. Чужорідне тіло захоплювали в затискач і видаляли. Для фіксації і вилучення металевих осколків у 26 (23,2\%) поранених застосовували магніт, який вводили ендовульнарно. За наявності ранового каналу довжиною понад 8 - 10 см у 19 (17\%) поранених кулю або осколок видаляли по найкоротшій відстані з додаткового доступу. Значно утруднювала візуалізацію наявність газу в м'яких тканинах, що потрапляв разом з чу- жорідним тілом або внаслідок пульсуючої порожнини. Виникало безліч ультразвукових артефактів, що імітували осколки. У частини пацієнтів через це видалення сторонніх тіл не було успішним. У таких ситуаціях повторні спроби вилучення проводили через $24-48$ год після резорбції газу.

\section{Обговорення}

Під час первинної хірургічної обробки сторонні предмети вилучені у 92 (82,1\%) із 112 поранених, під час повторної - у 16 (14,3\%). У 4 (4,6\%) поранених ультразвукове дослідження не дало можливості візуалізувати осколки: у 1 - в бічній області шиї, у 1 - у м'язах гомілки, у 2 - в грудній стінці. У всіх випадках спостерігали емфізему м'яких тканин. Газ у рані створював безліч візуальних артефактів, що ускладнювали диференціацію сторонніх тіл. Їх видалили під час повторної хірургічної обробки 3 широким доступом і використанням ЕОП. Ускладнень не спостерігали.

Розміри видалених сторонніх тіл за даними післяопераційних вимірювань: більше 3 см - у 6 (5,4\%) поранених, 2 - 3 см - у 14 (12,5\%), 1 - 2 см - у 38 (33,9\%), 0,3 1 см - у 54 (48,2\%). Сторонні тіла з металу (деформовані кулі, оболонки куль, осколки снарядів) видалені у 98 (87,5\%) поранених, скла - у 6 (5,4\%), каменю - у 4 (3,6\%), дерева - у 2 (1,7\%), пластику - у 1 (0,9\%), матерії - у 1 $(0,9 \%)$. Таким чином, у 82,1\% поранених основної групи переважали металеві осколки розмірами до 2 см.

Ми застосували сонографію так само для інтраопераційної навігації при лапаротоміях для диференціації анатомічних структур великих заочеревинних гематом і чужорідних тіл у паренхіматозних органах. 3 цією метою використовували мобільні ультразвукові апарати з конвексним або лінійним датчиком, на які надівали спеціальні чохли, що забезпечували стерильність дослідження. УЗД виконувалося з використанням не гелю, а стерильного фізіологічного розчину. На даний момент аналізувати ефективність, специфічність і ступінь достовірності досліджень неможливо через малу вибірку спостережень - 1 пацієнт з осколком в заочеревинній гематомі і 1 пацієнт з кулею в паренхімі печінки. В обох випадках визначили ступінь пошкодження органів, локалізацію стороннього тіла і безпечний доступ для його видалення.

Таким чином, УЗД, що є безпечним для лікаря і пацієнта методом, показало високу ефективність в діагностиці та лікуванні вогнепальної рани, особливо в умовах обмежених технічних можливостей (АТО). Застосування ультразвукової навігації при порожнинних операціях потребує подальшого вивчення і підготовки суміжних фахівців у галузі хірургії та радіології.

\section{Висновки}

1. Застосування в комплексі лікувально-діагностичної програми ультразвукової навігації на 18,2\% підвищує частоту диференціації і видалення сторонніх тіл - куль і осколків під час первинної хірургічної обробки рани та на 7,8\% знижує необхідність повторних втручань.

2. Перевагами методу є: мобільність, висока інформативність щодо структурних порушень м'яких тканин і верифікації чужорідних тіл, особливо не металевих. 
Видалення сторонніх тіл під контролем ультразвуку дозволяє проводити операцію в режимі реального часу без променевого навантаження на пацієнта і медичний персонал.

3. У 4,6\% поранених з емфіземою м'яких тканин сторонні тіла не диференціювались. Газ у рані створював безліч візуальних артефактів, що значно ускладнювало проведення дослідження та операції.

\section{References}

1. Berezka NI, Vlasenko VH. Ognestrelnye rany. Lechenie na jetapah medicinskoj jevakuacii: metodicheskie ukazanija. Kharkov: KhNMU; 2015. 43 p. [In Russian].

2. Humanenko EK. Politravma. Aktual'nye problemy i novye tehnologii $\mathrm{v}$ lechenii. In: Novye tehnologii v voenno-polevoj hirurgii i hirurgii povrezhdenij mirnogo vremeni. St. Petersburg; 2006. 4-14. [In Russian].

3. Chovanes J, Cannon JW, Nunez TC. The Evolution of Damage Control Surgery. Surg Clin North Am. 2012;92(4):859-75, vii-viii. doi: 10.1016/j.suc.2012.04.002. Epub 2012 Jun 5. 